\title{
GEOMORPHOLOGICAL PROCESSES IN CHANNEL HEADS INITIATED BY GROUNDWATER OUTFLOWS (THE PARSĘTA CATCHMENT, NORTH-WESTERN POLAND)
}

\author{
MaŁgorzata MazureK \\ Adam Mickiewicz University, Institute of Geoecology and Geoinformation, Poznań, Poland
}

Manuscript received: July 27, 2011

Revised version: September 5, 2011

\begin{abstract}
Mazurek M., 2011. Geomorphological processes in channel heads initiated by groundwater outflows (the Parsęta catchment, north-western Poland). Quaestiones Geographicae 30(3), Bogucki Wydawnictwo Naukowe, Poznań, pp. 33-45, 5 Figs. ISBN 978-83-62662-75-3. ISSN 0137-477X. DOI 10.2478/v10117-011-0025-x
\end{abstract}

AвSTRACT. Channel initiation is caused by a combination of various hydrogeomorphic processes. In the humid temperate zone of the Polish Plain, in areas with permeable deposits, seepage erosion is the primary mechanism of stream channel initiation. In the 24 channel heads selected in the southern part of the Parsęta catchment (NW Poland), the zones of occurrence of the following processes were identified: (1) seepage erosion; (2) falls, dry ravel events and slides; (3) creep, solifluction, surface runoff and erosion; (4) channel processes; and (5) landforms created under the impact of plants and animals. The co-occurrence of various morphogenetic processes produces variations in the accumulation conditions, and as a result, a diversity of deposits. Channel heads morphology shows the effect of the topography of the zero-discharge catchment, the type and magnitude of groundwater outflows, the variability of the geological structure, and the possibility of material being removed from the alcoves.

KEYWORDS: channel head, channel initiation, groundwater outflows, seepage erosion, Parsęta catchment

Małgorzata Mazurek, Institute of Geoecology and Geoinformation, Adam Mickiewicz University, Dziegielowa 27, 61-680 Poznań, Poland, e-mail: gmazurek@amu.edu.pl

\section{Introduction}

The channel head is a significant element of the headwater system (Hack \& Goodlett 1960, Gomi et al. 2002, Benda et al. 2005); it is a place where concentrated water flow and sediment transport start, and where bedforms evolve between distinctly developed channel banks (Dietrich \& Dunne 1993). The channel head should be readily identifiable in morphological and sedimentological terms, even in a period of flow disappearance. Its location is controlled by the relative magni- tudes of the sediment supply and the erosion potential, which is due to runoff and fluctuations in climate and land use; climate and land use alter runoff rates, surface erodibility and sediment supply and cause shifts in the channel head's position.

The channel initiation mechanisms are closely connected with the water flowpath characteristics of the slope system. In the 1980s, groundwater outflows became an object of independent research because they were considered to be a morphology forming factor that initiated seepage erosion 
and spring sapping (Dunne 1980, LaFleur (ed.) 1984, Higgins \& Coates (eds.) 1990).

In the lowland area of central Europe with its high sediment infiltration capacity, the excess of rain- or melt-water usually infiltrates into the soil and thus nourishes the groundwater, which is then drained by outflows. In such areas, groundwater seepage erosion can be the primary mechanism that controls channel initiation (De Vries $1976,1994)$ and the development of a valley head (Ahnert 1998).

Channel heads determined by groundwater outflows that assume the form of an alcove or a set of alcoves develop within hollows of varying genesis or dissect slopes to form their own headwater depressions (i.e., valley heads). The most important factor in their development is the emerging groundwater, which can be both an erosive agent and a factor that affects sediment erodibility. The formation of valley and channel heads is an effect of co-operation and interaction of such influences as chemical weathering, seepage erosion, slope processes, and fluvial accumulation and erosion; collectively, they can be termed headwater processes.

Still, groundwater outflows are not fully appreciated as a morphogenetic factor in temperate zones (Higgins 1984) due to climate fluctuations and changes in land cover that result in lowering of the groundwater table, which diminishes the significance of this erosional factor and weakens the coupling between the outflows and the erosional landforms associated with them. The morphological effects of groundwater action can also be obscured by fluvial processes, sheetwash and mass movement. The relations between those processes largely depend on the climatic conditions and the local properties of the sediment in which those forms develop (Howard \& McLane 1988, Baker 1990, Nash 1996). In addition, they are also being destroyed and deformed by the activity of plants, animals, and most recently humans.

Most research on river channels that has been carried out in the postglacial area of northern Poland to date has focused on large- and mediumsized rivers. Only a small proportion of studies have been conducted in first-order streams, even though they account for $44 \%$ of the drainage network's length in this part of Poland (Mazurek
2010). Perennial streams rise from lakes, peat bogs, other wetlands, or various types of groundwater outflows. Groundwater outflows create favourable conditions for the concentration of water that leads to the formation of first-order streams and, as a result, to the development of channel processes. Lack of data on the geomorphometry of channel heads makes it impossible to identify the nature of the erosional effect of groundwater outflows and their contribution to the formation of river valleys.

The morphology of the zones of groundwater outflows in the lowland area of Poland has only rarely been an object of study, whether as part of hydrological (Krzemiński 1989, Maksymiuk \& Moniewski 2000, Moniewski 2004) or geomorphological research (Churska 1965, Bujwid \& Muchowski 1973, Banach 1977). There have also been few detailed descriptions of the sedimentological and geomorphological processes that occur in channel heads, which would indicate their formation mechanism.

The objectives of the present study is to discuss the dominant processes and landforms developed as a result of groundwater outflows in headwater zones. The geomorphological and lithological studies performed made it possible to obtain a picture of how channel heads operate in the postglacial zone of the Polish Plain.

The area chosen for the study was the southern part of the Parsęta catchment (NW Poland), where 1057 headwater streams have been identified on the basis of a topographic map at a scale of 1:10 000. With a mean length of $339.5 \mathrm{~m}$, headwater streams contribute $34 \%$ to the river network, which is a relatively low value that reflects the network's poor development in this area (Mazurek 2010). Those initiated by groundwater outflows constitute about $8.3 \%$. The study was performed in 88 channel heads (Fig. 1a) in which groundwater outflow was found to occur.

\section{Study area}

\section{Environmental variables}

The study area comprises the southern part of the Parsęta catchment, which covers an area of $617.2 \mathrm{~km}^{2}$ and is situated in the borderland be- 


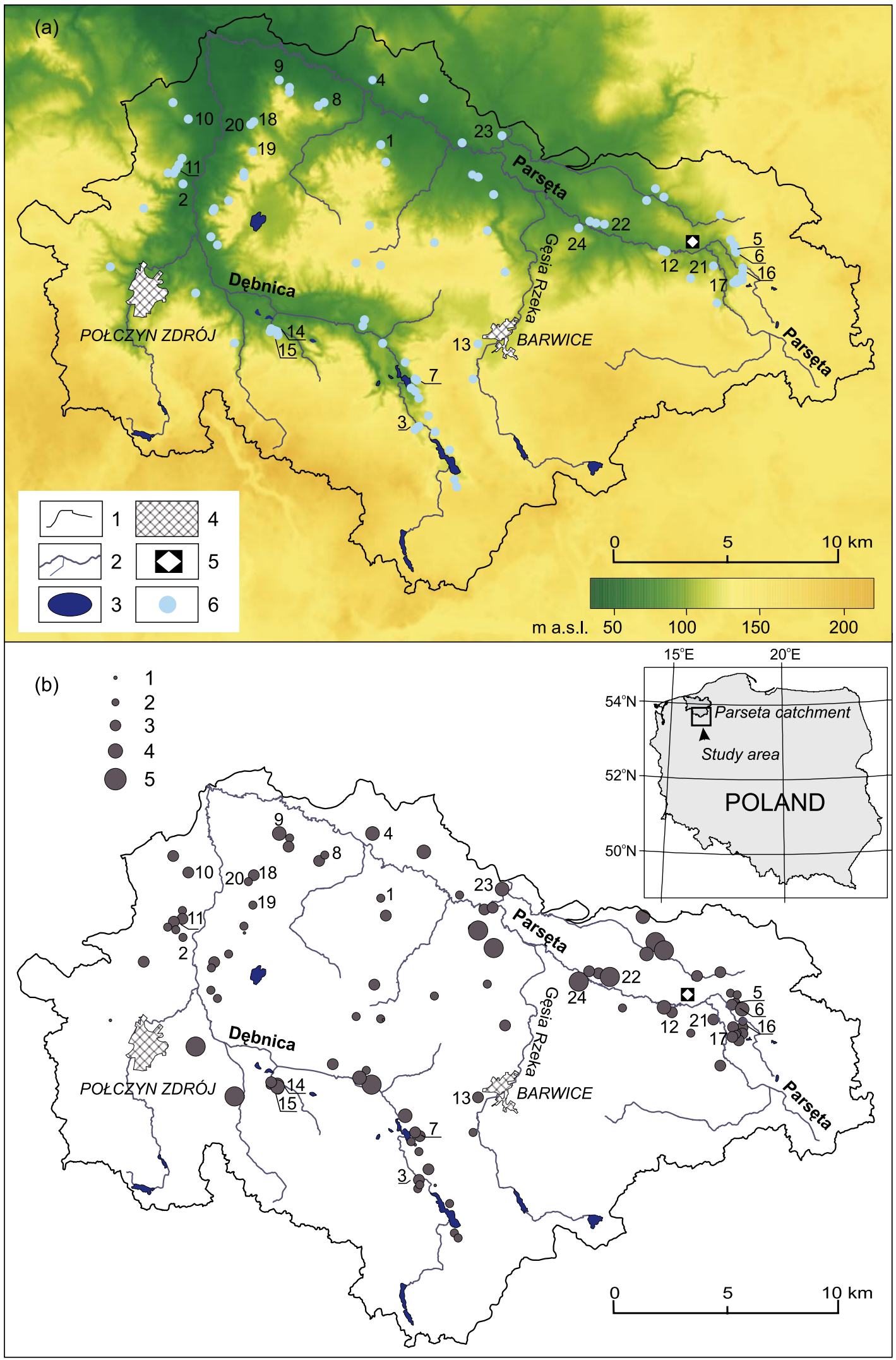

Fig. 1. Study area in the Parsęta catchment (NW Poland).

(a) Location of the study sites. Channel heads in which topographic measurements and morphological mapping were carried out bear ID numbers; 1 - study area, 2 - stream network, 3 - lake, 4 - town, 5 - meteorological station, 6 - channel head

(b) Discharge of the groundwater outflows: $1-<0.1 \mathrm{dm}^{3} \mathrm{~s}^{-1}, 2-0.1-1.0 \mathrm{dm}^{3} \mathrm{~s}^{-1}, 3-1.0-5.0 \mathrm{dm}^{3} \mathrm{~s}^{-1}, 4-5.0-10.0 \mathrm{dm}^{3} \mathrm{~s}^{-1}, 5-10.0-100.0 \mathrm{dm}^{3} \mathrm{~s}^{-1}$ 
tween the South Baltic Lakeland and the South Baltic Coastal Lowland. Its relief started to form 14-15 thousand years ago when the Vistulian ice sheet began to retreat from northern Poland during the Pomeranian Stage. Deglaciation has produced a mosaic of morainic uplands and glaciofluvial plains that are dissected by a network of troughs and erosional valleys. In hypsometric terms, the area is a lowland, but some of its parts, e.g. the end-morainic hills of the Pomeranian Stage, exceed $200 \mathrm{~m}$ a.s.l.

In the Parsęta basin's geological structure, a fundamental role is played by the complex of 15- to 214-m-thick Pleistocene and Holocene deposits, which comprise five and locally six levels of tills, glaciofluvial sands and gravels, river sands, and ice-dam silts and sands. The surface is covered with loose Pleistocene deposits: tills, glaciofluvial sands and gravels, as well as Holocene river sands, peat and colluvial deposits. The valley network consists of polygenetic depressions that were produced by the glacial/periglacial cycle and include subglacial tunnels, melt-out depressions, valleys left by proglacial water flow, and an ice-marginal valley. Among younger elements included in the network are short denudationalerosional valleys and gullies. The present-day relief is largely controlled by chemical denudation, erosion, fluvial accumulation, human-generated degradation and aggradation processes (Kostrzewski et al. 2008).

In the study period (2000-2005), the mean annual air temperature was $7.9^{\circ} \mathrm{C}$, whereas the mean annual rainfall amounted to $691 \mathrm{~mm}$. Precipitation in the warm half-year was higher than in winter (58\% of the annual figure), with snow contributing a mere $17.7 \%$ to the total. The frequency of heavy and torrential rains was low, and they usually occurred at the height of the vegetation season; rain intensity seldom exceeded the current water-holding capacity of the soil.

The land-use pattern in the southern part of the Parsęta catchment is an agricultural-woodland one, with agricultural land taking up 55.9\% and woodland (mainly conifers) and semi-natural ecosystems taking up $42.4 \%$. Grassland that is connected with drained mineral-organic and organic soils occupies $6.3 \%$ of the catchment area.

In the channel heads studied there are specific ecological conditions created by the stable tem- perature of water and its chemical composition (a high content of $\mathrm{Ca}$ and $\mathrm{HCO}_{3}$ ions). The microclimate, often poor light, saturated sediments and high water-flow velocities are favourable to the occurrence of 8 spring communities of the Montio-Cardaminetea class and 4 independent moss communities Fontinaletea antipyreticae (Osadowski et al. 2009).

\section{Hydrogeology and groundwater outflows}

The diversity of hydrogeological conditions results in various types of channel-initiating outflows. This largely occurs in the contact zones between glaciofluvial or fluvial sand-gravel deposits, glacial sands or erosion pavement and their underlying semi-permeable tills or poorly permeable loamy sands. Water-bearing horizons display permeability of $10^{-3}-10^{-5} \mathrm{~ms}^{-1}$. Channel heads develop within a variety of landforms in areas with substantial height differences, i.e., on scarps of morainic uplands, slopes of subglacial tunnel valleys, kettle-holes, river terraces, and slopes of both kame hummocks and dead-ice moraines. Outflows are located in variously developed headwater alcoves that are channel heads and also in $80 \%$ of valley heads.

Unconfined groundwater from the local near-surface aquifer feeds seepage faces, seepage springs and various types of discrete springs (such as contact springs, depression springs, and barrier springs; Younger 2007) located not only in the footslope zone but also in the shoulder and backslope zones of headwater hollows. A characteristic feature of the study area, which is built of loose sediment with varying permeability, is the occurrence of various types of outflow (springs and seepages) clustered in a small area that is called a seepage spring area. The outflowing water is carried away from it by a stream that gradually forms into a river channel. In the footslope zone, there are efficient ascending springs fed by confined waters from regional and intermorainic aquifers.

The discharge volume of the 88 headwater streams under study varies between 0.01 and $71.76 \mathrm{dm}^{3} \mathrm{~s}^{-1}$ (Fig. 1b). Measurements of the flow in the channel heads in September 2004 showed that $43.2 \%$ of them were fed by groundwater out- 
flows of a very low discharge, less than $1 \mathrm{dm}^{3} \mathrm{~s}^{-1}$. Next came outflows discharging from 1 to $5 \mathrm{dm}^{3}$ $\mathrm{s}^{-1}(35.2 \%)$. There were 9 with the highest discharges, from 10 to $100 \mathrm{dm}^{3} \mathrm{~s}^{-1}(10.2 \%)$.

\section{Methods}

Field surveys were conducted in the study area during 2000-2005 to map the locations of channel heads that were initiated by groundwater outflows, see Fig. 1. From among the 88 channel heads, 24 sites were selected for topographic and geomorphological surveying (Fig. 1b). The exact topographic measurements were taken by using a combined method that employs a GPS receiver (Leica SR530) and a total station (ELTA R55w). Vector and grid layers that present the relief and water network were analysed by using the GIS CartaLinx and Idrisi Kilimanjaro programs. Some of the thematic layers were visualised with the help of the Surfer 8.04 program. On the basis of the digital elevation models of the channel heads, their cross-sections and long profiles were constructed.

The channel head area was determined on the basis of the range of occurrence and morphological impact of groundwater outflows, but the overlap of the slope processes on the slopes of hollows and alcoves sometimes made their clear delineation difficult. In the 24 channel heads, the zones of occurrence of the following processes were identified during field investigations and mapped: (1) seepage erosion; (2) falls, dry ravel events and slides; (3) creep, solifluction, surface runoff and erosion; (4) channel processes; and (5) landforms created under the impact of plants, animals and humans. In 2004, as a supplement to the study of surficial deposits in channel heads, a detailed lithological mapping was carried out within eight of them. For sampled sediment cores with lengths ranging from 0.5 to $5.5 \mathrm{~m}$, an analysis was performed of the grain-size composition (using a combined method of sowing and sedimentation) and the content of organic matter due to loss-on-ignition at $550^{\circ} \mathrm{C}$ (LOI). For the purpose of the analysis, the organic matter content $(\mathrm{OM})$ was assumed to be equal to the LOI.

\section{Research results}

\section{Mechanism of headwater zone formation}

The channel heads under analysis differ in size and hypsometry (Mazurek 2006). The biggest headwater alcove has an area of 4.3 ha (measurement on a topographic map at a scale of 1:10 000). The areas of the 24 alcoves in which tachymetric measurements were performed range from 0.02 to $0.53 \mathrm{ha}$, whereas their bottoms range from 0.007 to 0.46 ha.

The repeated morphological mapping of the 24 headwater areas revealed the presence of meso- and micro-landforms that were created by surface water, groundwater, mass movement, as well as the impact of plants, animals, and humans. The mapping made it possible to distinguish two basic groups of morphogenetic processes in the channel heads.

One group embraces headwater areas with mean slope gradients of up to $38^{\circ}$ and a steady groundwater outflow (Figs 2, 3, 4). Water exfiltrates in them in the footslope zone; this leads to the undermining and removal of the basal support as well as its collapse along a seepage face. This seepage erosion promotes headward and side slope migration of the alcove. The wash-out of deposits at the foot of the slopes leads to the formation of low erosional undercuttings that are further developed by failure. Their depth can attain tens of centimetres, but they are often masked by vegetation. The undermining of the stability of the high slopes produces falls, slumps and shallow landslides. The movement starts at the site of water outflow and advances upslope, where it stops. Its range varies between tens of centimetres and a few metres. The depth of the earth's slide zone does not exceed $0.5-1 \mathrm{~m}$ in the studied alcoves.

Locally, in the case of the steep, sparsely vegetated slopes of alcoves built of sand deposits, dry, loose material is found to move from the slopes to the bottom via dry ravel. In the upper and central parts of the slopes, there are traces of sheetwash and sometimes erosion, which can be facilitated by uprooted trees and animal action. The material that is transported by mass movement temporarily accumulates in the form of colluvial and small alluvial-colluvial cones at slope 

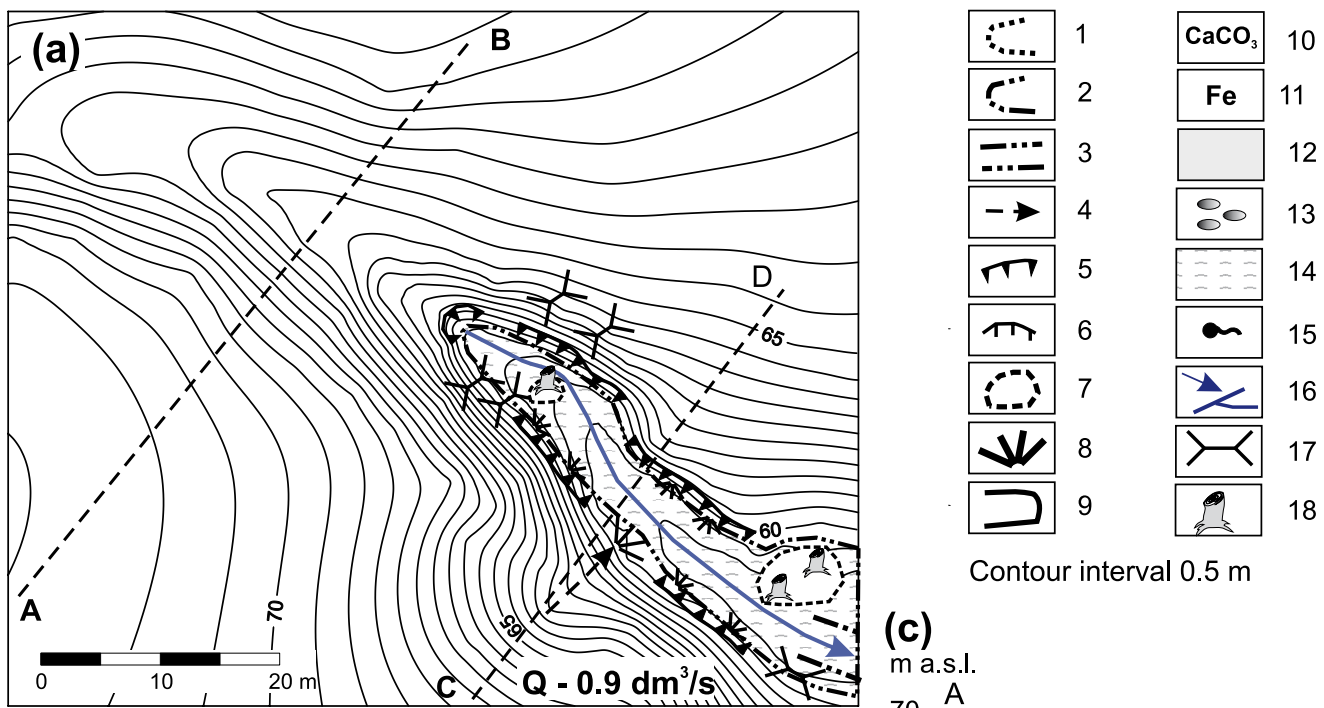

Contour interval $0.5 \mathrm{~m}$

(c)
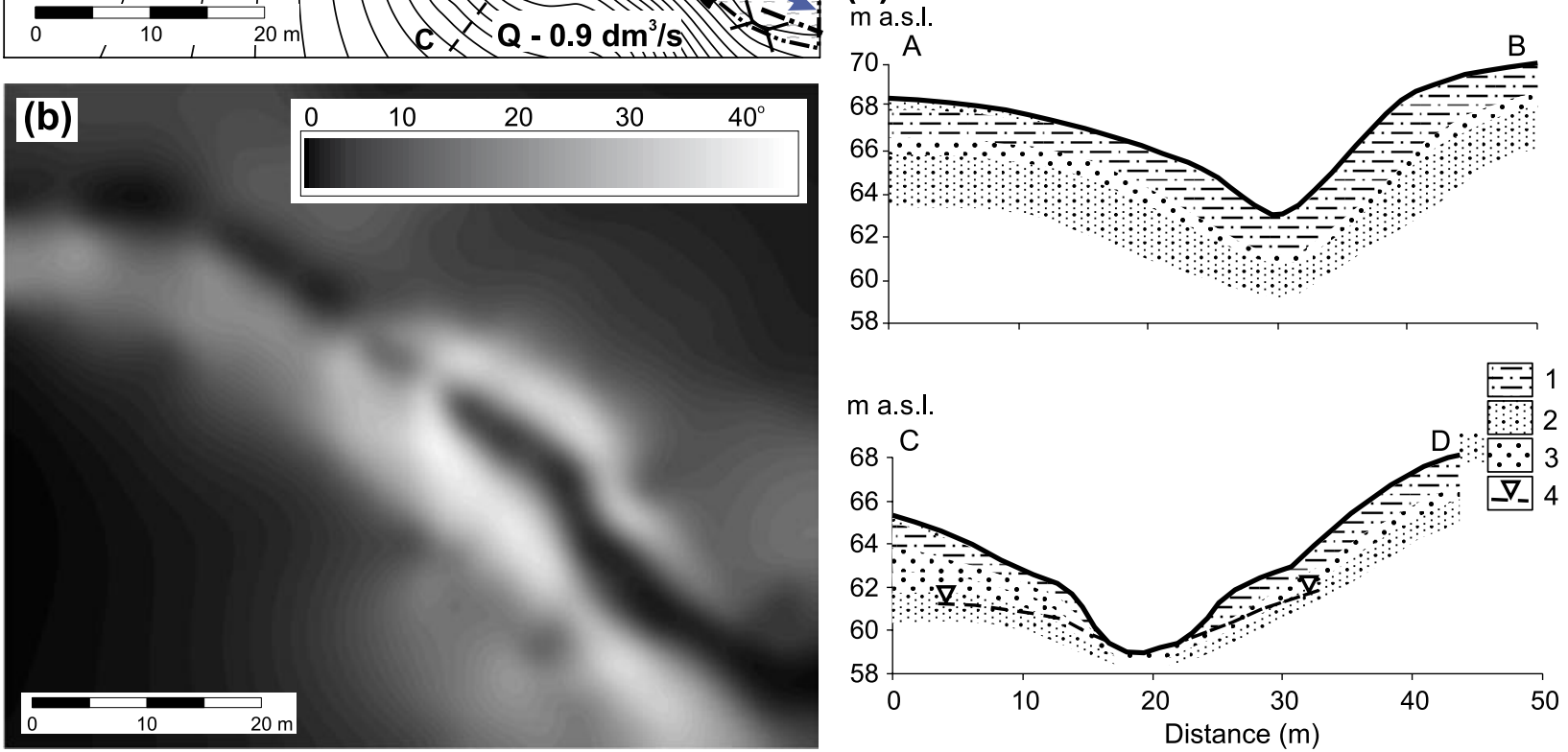

Fig. 2. Channel head Buślary 2 (ID 2).

(a) contour map with locations of selected geomorphic activity and hydrological elements: 1- slope processes zone, 2 - seepage erosion zone, 3 - fluvial processes, 4 - episodic rill wash, 5 - seepage erosion scarp, 6 - landslide scar, 7 - erosion residuals, 8 - sediment fan, 9 - spur, 10 - calcium precipitation, 11 - Fe precipitation, 12 - organic sediment, 13 - erosional pavement, 14 - seepage, 15 - spring, 16 - drainage line, 17 - fallen tree, 18 - tree, trunk

(b) slope gradient map derived from DEM obtained by ground survey,

(c) cross-section profiles with lithology: 1- silty sand, 2- fine sand, 3 - medium sand with gravel, 4 - groundwater level.

breaks. These landforms initially hinder the free outflow of water from the subslope zone and block further headward erosion advances. During the mapping, colluvial deposits have been observed to be carried away and colluvial cones washed out.

In an alcove bottom that is built of loose sand deposits, in the zone where the water level has stabilised above the ground, exfiltrating water flowing in sheets across the bottom reduces the effective weight of the grain material and facilitates its detachment and removal down to the river channel that has formed below. Water flowing out in the bottom of such an alcove washes it out and deepens it; as a result, the material left on the surface is an erosional pavement (medium sand with gravel, Fig. 3), while fine sediment is carried away to the river channel below. The deepening is indicated by the appearance of steps $(0.5-2.5 \mathrm{~m}$ high) in the bottom that close the channel heads cutting into the gullies.

In channel heads with smaller slope gradients and low-discharge outflows in the footslope zone, there is an accumulation of sediment from the slopes, which includes fine plant detritus (Fig. 4). In those channel heads, erosional proc- 

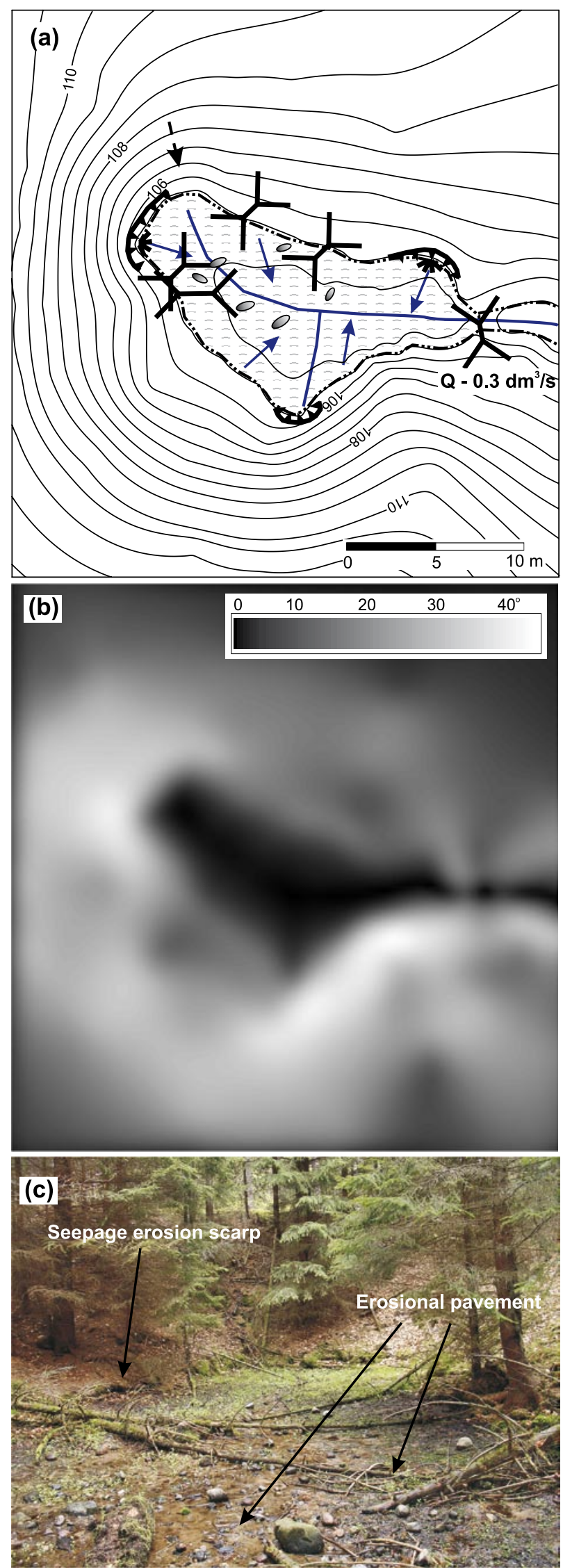

esses are concentrated within the bottom, which undergoes wash-out, deepening, and thus levelling out, which is proved by low gradients.

The other group of channel heads is characterised by headwalls that attain heights of up to a few metres and that widely differ in gradients with small flat sections (Fig. 5). This smaller group of channel heads (17 sites) owes its development to slope outflows (also ascending outflows). Seeps and small springs are located at various heights on the slopes of a head or directly at the bottom. Their occurrence is due to great lithofacies differences in glacial deposits, the shape of the impermeable layer's top, and the variable depth of the near-surface water table within the alcove. Some of the small outflows dry up in rainless periods and freeze over in winter, which confirms that they are fed by throughflow.

An effect of the diversified morphology, lithology, and thus the depth to the groundwater table is a mosaic of areas within the alcoves that differ in moisture and susceptibility to erosional processes. In the exfiltration zones, saturated areas extend seasonally in which the pressure head stabilises periodically above ground level. Those zones are heavily dependent on the local topography. Saturated areas are eroded by saturation overland flow or return flow. Slope groundwater outflows initiate small rivulets of water whose erosional action dissects the slopes. On the slopes, one can observe small, spur-like ridges that turn into erosion residuals with advancing fragmentation (Figs 4 and 5). Outflow sites on the slopes are confined by low erosional scarps (up to $0.7 \mathrm{~m}$ in height) that formed by seepage erosion and that retreat slowly under the influence of gravitational processes. In effect, they develop small flat areas that lead to the formation of the slope's stepped long profile, which was termed a seepage slope by Tanaka (1982). The steps on the slopes that define the stepped profile can also develop on tree detritus with overlying slope wash deposits.

In places where seepage does not generate runoff but only increases the moisture content of surficial deposits, conditions are favourable

Fig. 3. Channel head Rudno 2 (ID 19): (a) contour map with locations of selected geomorphic activity and hydrological elements, legend from Fig. 2 a, (b) slope gradient map derived from DEM obtained by ground survey, (c) photo of channel head Rudno 2 with erosional bottom (June 2004). 

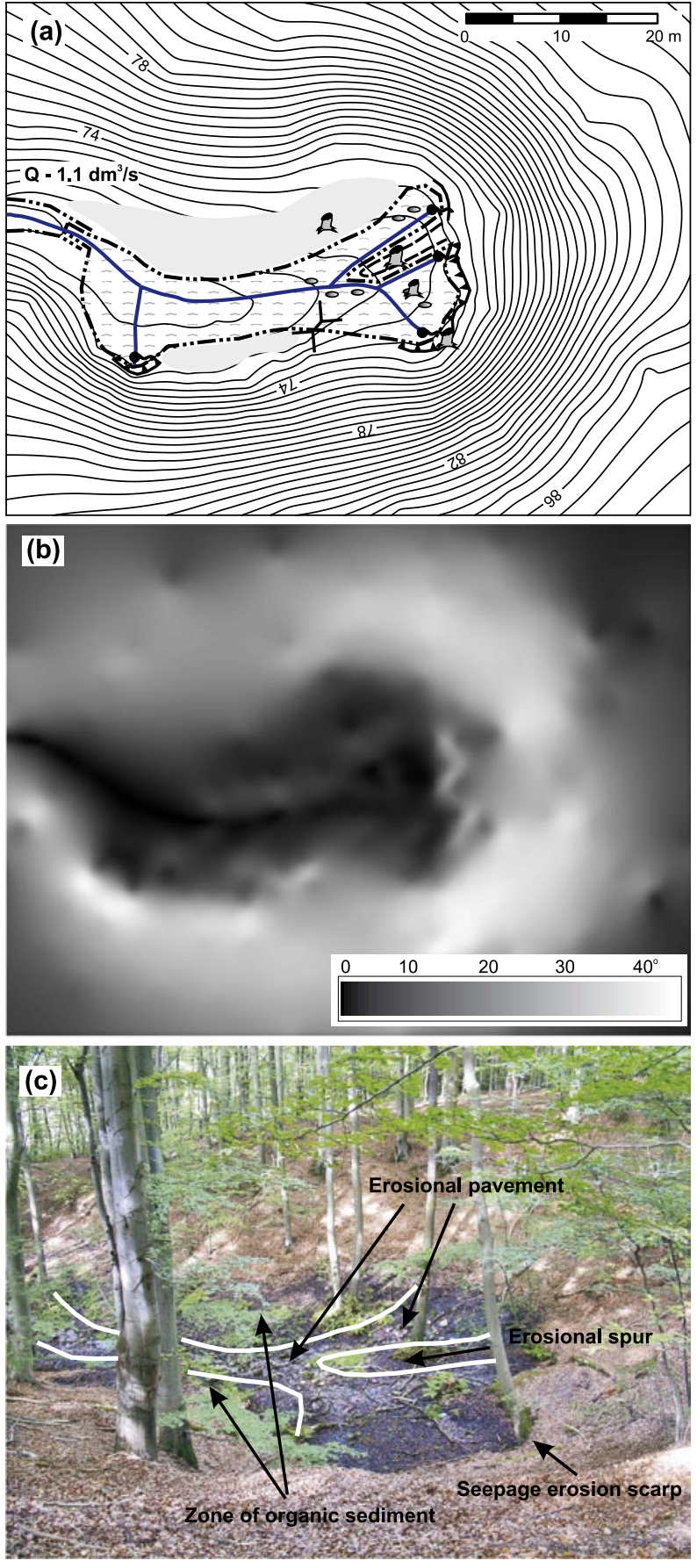

Fig. 4. Channel head Rudno 1 (ID 18).

(a) contour map with locations of selected geomorphic activity and hydrological elements, legend from Fig. 2 a, (b) slope gradient map derived from DEM obtained by ground survey, (c) photo of channel head Rudno 1, (September 2004)

for the accumulation of organic matter. A rise in the level of the near-surface water, especially in the winter-spring period, brings about a periodic saturation of patches of organic-mineral deposits and peat. The water makes the deposits wetter and loosens the compactness of the slope mate- rial, which slowly flows over the near-surface organic-mineral layer and causes the thickness to vary depending on the land's gradient (Fig. 5). The depth of the movement zone does not exceed 0.3-0.5 $\mathrm{m}$. The movement of the deposits leads to slope stripping, which is also indicated by exposed tree roots.

On slopes without groundwater outflows, it is possible to observe deposit creep that is caused by animals moving across the slope, while in winter, the movement of land that is devoid of plant cover is facilitated by needle ice. When frost occurs on the ground, needle ice develops right under the surface and pushes up particles of deposits. During the day, the needles melt, break and topple, and the pushed-up material shifts or creeps downslope.

\section{Discussion}

\section{Factors promoting the development of channel heads}

This study supplies quantitative data about the size of channel heads in lowland areas driven by groundwater seepage that are cut in glaciofluvial sands and gravels or glacial gravel-silt sands underlain by till. The morphological characteristics of small channel heads, which formed in unconsolidated sediments, corroborate the observations presented, e.g., by Uchupi \& Oldale (1994) and Schumm et al. (1995). In the cross profiles of the studied alcoves with outflows located in subslope positions (outflows emerge at the base of a head that terminates a valley), it is possible to distinguish a flat bottom, a straight slope with a considerable gradient, and a concave section that joins those two elements and is also connected with the erosional zone of groundwater outflows. The profiles are analogous to those obtained in laboratory experiments (Howard \& McLane 1988) and verified by field measurements in the Florida Panhandle by Lobkovsky et al. (2007). In the study area, the slopes have complex shapes too, which is common within landforms with slope outflows. Around each of the outflows, seepage erosion can produce low steps, which forms what Tanaka (1982) calls a seepage slope. Such a slope profile shows the effect of de- 

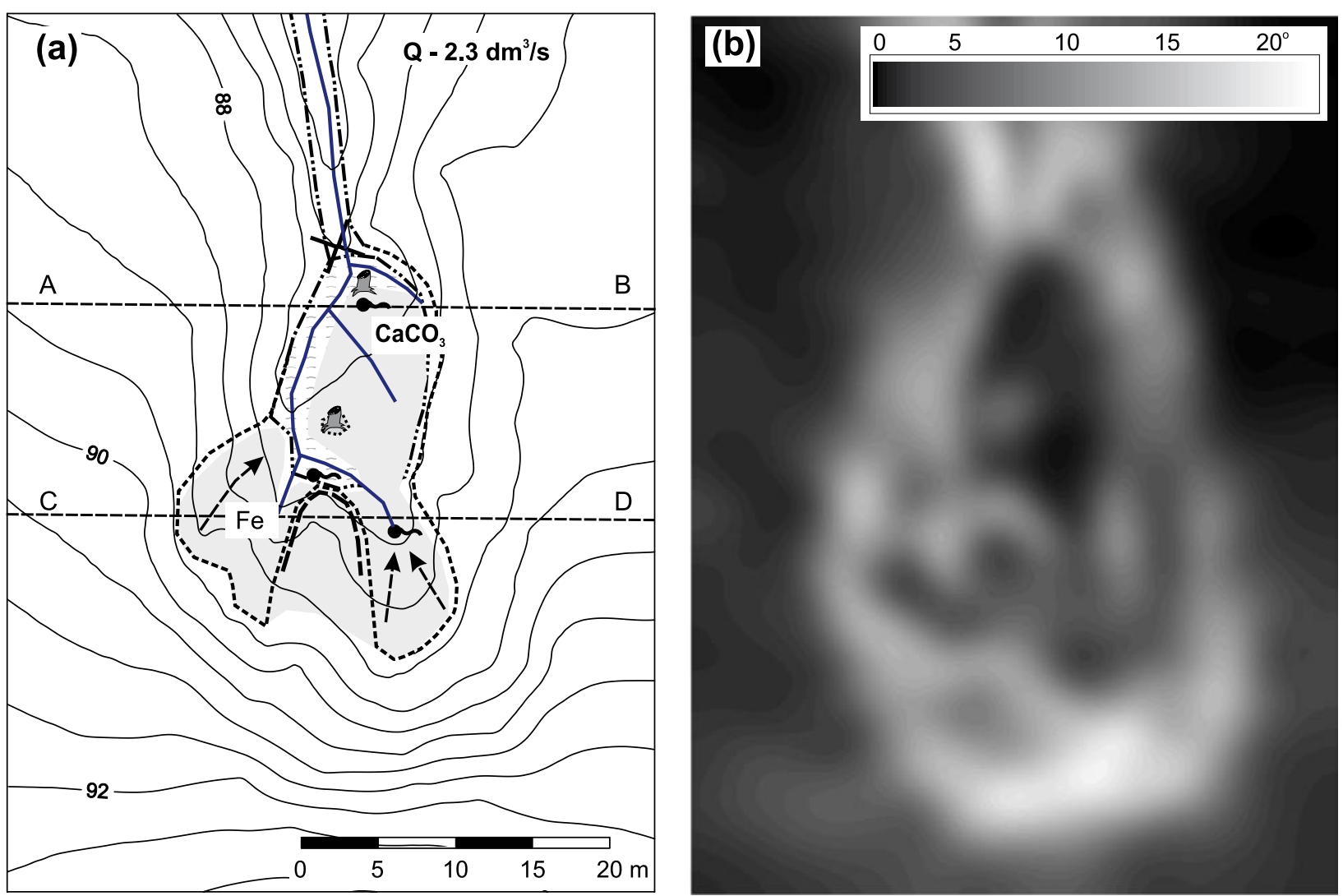

(c)

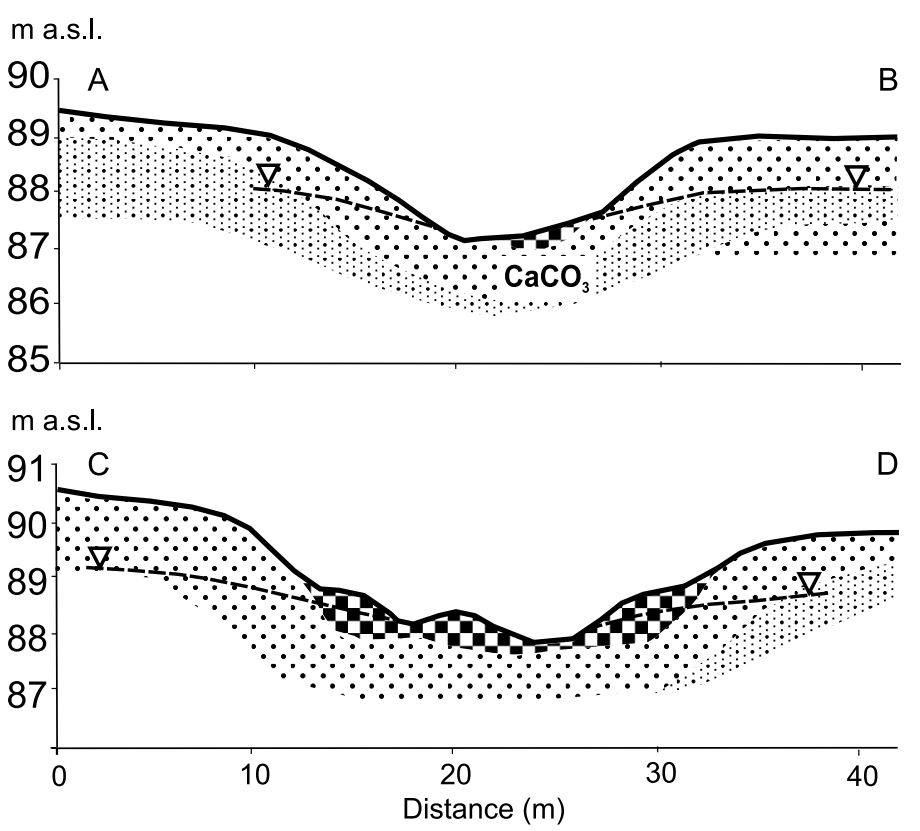

Fig. 5. Channel head Parsęta 2 (ID 12).

(a) contour map with locations of selected geomorphic activity and hydrological elements, legend from Fig. 2 a, (b) slope gradient map derived from DEM obtained by ground survey, (c) cross-section profiles with lithology: 1 - peat, 2 - fine sand, 3 - medium sand with gravel, 4 - groundwater level, 5 - calcium precipitation

posit lithology on the directions of groundwater flow and the location of its outflows. The scattering of the outflows, which is characteristic of the studied geological conditions, also leads to the formation of spurs and residuals on the slopes and thus advances alcove fragmentation (Fig. 5). 
The lithology and stratigraphy of Pleistocene and Holocene deposits controls the shape, orientation and size of the alcoves through the position of the water-bearing layer's bottom and step-like changes in its thickness and conductivity; thus, it decides the direction of groundwater inflow, the concentration or scattering of outflows, their discharge volume, and the location at various slope elevations (footslope or slope outflows). This impact of the lithological factor is readily visible in alcoves that developed in morainic uplands, where the lithological variability of gravel-silt sands and their interbedding by deposits with a low permeability (like tills) contribute to the appearance of unconcentrated outflows as well as their scattering throughout an alcove. The morphology of headwater alcoves is determined by the efficiency of relief-forming processes, which partly depend on the erodibility of deposits that build the groundwater-seepage heads.

The morphometry of the group of elongated and narrow alcoves in the southern part of the Parsęta catchment is similar to the landforms in the Łódz Hills (Central Poland), which were examined by Maksymiuk \& Moniewski (2000) and Moniewski (2004). Their common morphological features result, among other things, from the similarity in the geological structure (glacial sands and tills, fluvioglacial sands) and hence from the groundwater flow conditions and outflow type. In the Łódz Hills, the elongated shapes of the channel heads resemble the unchannelled valleys that are situated above them and produced by erosion from surface runoff. Hence, the relief should be regarded as an environmental factor that is responsible for the geometry of the alcoves at an initial stage of their development. Some $(27.3 \%)$ of the alcoves in the study area are inserted into older denudational-erosional valleys, whose bottoms and slopes are now being modified by seepage erosion. Schumm \& Philips (1986) describe a similar two-stage composite origin of the channel heads that dissects the cliff coast of the Canterbury Plain in New Zealand. The morphometric differences among such alcoves reflect the original relief, like the elongation of the initial forms and a gentle transition between the bottom and slopes of the denudational-erosional valleys (Fig. 2). The gradient of the alcove bottoms at the initial stage of formation also imitates that of the initial landforms in which the alcoves develop. Depending on headward erosion, gravitational mass movements (falls and small slides, slumps), and the possibility of deposits being removed by water, the alcoves grow in width and depth. A similar contribution of the repeating processes to slope retreat was observed by Onda (1994) during his research in Japan. Such a pattern of processes leads to the formation of steeply inclined alcove slopes with a distinct concave section at the foot that passes into a flat bottom (Figs 3 and 4).

\section{Sediment production in channel heads}

The repeated morphological mapping of the channel heads has revealed a group of hillslope processes that are responsible for supplying sediment to the channel. Those observations corroborate the conclusions drawn by Banach (1977), Dietrich \& Dunne (1993), Nash (1996), and Schumm \& Phillips (1986) that it is the joint action of groundwater, surface water (overland flow, through flow, and channel flow) and gravitational processes that shape valley and channel heads. The intensity of those processes is controlled by such external factors as precipitation, snow cover, needle ice, icing, as well as the activity of plants, animals and humans.

Some of those processes take place all year round, though with varying intensity, e.g. seepage erosion and channel processes. Gravitational processes and surface wash are periodic or even episodic occurrences. The development of channel heads and the supply of material are especially intensive in the winter season as a result of high-discharge groundwater outflows, needle ice and snowmelt action; in summer, the degradation of their slopes is controlled by plants and antecedent soil moisture. The needle ice develops during winter in the contact zone between the surface layer of deposits with a lower moisture content, which are underlain by a wetter layer. The needles loosen the deposits, which helps to initiate and then facilitate the transport of material by sheet wash (Gerlach 1966, Lawler 1993). The effect of this action depends primarily on the number of freeze-thaw cycles during winter, but also on the mechanical composition of the deposits (fine-grained structures are preferred) and 
their moisture. During the hydrological years 2000-2005, in the study area, the number of days with favourable conditions for the development and disappearance of needle ice was 434 (from 71 days in 2001 to 108 in 2003). Those figures indicate a potentially high frequency of needle ice and its share in the movement of the surficial layer in the deposits (Mazurek 2010).

In the group of channel heads with steep slope gradients and flat bottoms covered by an erosional pavement (Fig. 3), groundwater outflows create conditions favourable for water concentrating in the subslope zone and removing material from the headwater zone. However, when the flowing water is low or the supply of colluvial sediment from the slopes is large, the transport capacity of the water is insufficient for it to carry the material away, which usually temporarily stops alcove development. The transport of deposits from a headwater alcove can also be checked by human activity, which forces the accumulation of material in the alcove's bottom (e.g. by building causeways, water gates and ponds); thus, the local erosional base is altered. In the group of alcoves with low slope gradients, which often have a long stepped profile and scattered lowdischarge groundwater outflows (Fig. 5), colluvial deposits, organic-mineral muds and patches of peats were found to occur. This is indicative of at least a periodic accumulation of deposits in the slope and/or subslope position, often with the help of vegetation. In those cases, the zones that supply deposits to the river channel are the water flow pathways down the slopes of the channel heads. With a shift in groundwater outflows away from the slopes (Figs 3 and 4), they attain stability, and erosion concentrates in the bottom zone.

\section{Conclusions}

In the geological, geomorphological and climatic settings of Pomerania (NW Poland), seepage erosion is one of the major geomorphic processes responsible for the development of channel networks. The observations indicate that despite their small size, channel heads, which develop predominantly by groundwater erosion, are often a distinctive feature of postglacial relief in the southern part of the Parsęta catchment. The alcove's morphology shows the effect of the topography of the zero-discharge catchment (the morphology of initial depressions), the type and magnitude of groundwater outflows, the variability of the geological structure, and the possibility of material being removed from the alcoves. The discussed factors agree with those listed by Howard \& McLane (1988), Baker (1990), and Nash (1996).

The channel head extension is usually controlled by several processes and not only by erosion from groundwater outflow, which is documented by the morphological mapping performed. The observed complexity of the processes involved in groundwater exfiltration results from the fact that it can bring about slope instability in the alcoves under study via two separate but interrelated mechanisms. The stimuli to mass movement in the headwater alcoves have been found to include the following:

- Seepage erosion, which is a hydrostatic and hydrodynamic effect of water exfiltrating at the foot of and on a slope; this undercuts the slope, disturbs its balance and finally leads to slumps and earth slides.

- Saturation with exfiltrating water from the deposits that cover the slopes, which increases the pore pressure and lowers the resistance of the deposits; thus, solifluction and creep is produced in the water-logged substratum.

Morphological mapping shows the contribution to relief formation of seepage erosion and mass movement to be different in the individual alcoves. Erosion caused by overland flow plays an insignificant role at present, but its effect is still visible in the development of alcoves that dissect small denudational-erosional valleys. Seepage erosion is a continuous process whose efficiency changes with the groundwater level; hence, it is seasonal in nature and controlled by climatic conditions. The season that is most favourable to erosion from water exfiltration with a free water table is the spring (March-April), whereas those with a confined water table rise to the highest stages from May to August. The rate of alcove development is assisted by mass movements, such as falls and landslides, which are usually stepwise in pattern. The headwall erosion rate is also limited by the rate of sediment removal. The 
laboratory experiments performed by Howard \& McLane (1988) show that 'transport-limited' behaviour is characteristic of seepage erosion of non-cohesive sediments. Future research that is based on long-term observations of runoff and sediment transport is required to quantify channel initiation processes and headwater landforms. Future research that is based on long-term observations of runoff and sediment transport is required to quantify channel initiation processes and headwater landforms.

The removal of material supplied from the slopes and its inclusion into channel transport makes headwater alcoves direct links between the slope system and the channel system. This is a distinctive feature of channel heads in postglacial Pomerania, where even during extreme meteorological and hydrological events, the coupling of the slope denudation system with the fluvial transport system is tenuous (Kostrzewski \& Zwoliński 1992). A period of headward and lateral development in the alcoves can be followed by slope stabilisation, which results from changes in the slope gradient and fixing of the slopes and bottom by vegetation. The coupling between the slopes and the channel weakens. On attainment of slope equilibrium, seepage erosion is concentrated in the alcove's bottom and restricted to its deepening. Changes in the discharge volume of the outflows and their transport capacity can lead to increased accumulation in the alcoves, fixing of deposits by vegetation, and discoupling of channel head units.

\section{Acknowledgements}

I am grateful to the staff of the Geoecological Department of Adam Mickiewicz University in Poznan and Storkowo for their help during fieldwork. This research has been partly funded by the Committee of Scientific Research (project no 3PO4E 04323).

\section{References}

AHNERT F., 1998. Introduction to geomorphology. Arnold, Londyn.

BAKER V.R., 1990. Spring sapping and valley network development, with case study by Kochel R.C., Baker V.R., La- ity J.E., Howard A.D. In: C.G. Higgins, D.R. Coates (eds.), Ground water geomorphology: The role of subsurface water in Earth-surface processes and landforms. Geol. Soc. Am., Spec. Paper 252: 235-290.

BANACH M., 1977. Rozwój osuwisk na prawym zboczu doliny Wisły między Dobrzyniem a Włocławkiem (The growth of landslides on the right-bank slope of the Vistula Valley between Dobrzyń and Włocławek). Pr. Geogr. 124: 1-101.

Benda L., Hassan M.A., Church M. \& May C.L., 2005. Geomorphology of steepland headwaters: the transition from hillslopes to channels. J. Am. Water Resour. Assoc. 41(4): 835-851.

BujwiD H. \& Muchowski J., 1973. Rola naturalnego drenażu wód podziemnych $\mathrm{w}$ rozwoju morfologicznym krawędzi dolin rzecznych na przykładzie wybranych odcinków dolin: Wisły i dolnej Bugo-Narwi (Contribution of natural groundwater drainage in the morphological development of river valley margins on the example of some selected sections of the Vistula and Bugo-Narew river valleys). Przegl. Geol. 7: 396-400.

Churska Z., 1965. Późnoglacjalne formy denudacyjne na zboczach pradoliny Noteci-Warty i doliny Drwęcy (The late glacial denudative land forms occurring on the slopes of the Noteć-Warta ice-marginal streamway and the Drwęca valley). St. Soc. Scien. Torunensis, Sec. C, Geographia et Geologia 6: 1-112.

DE VRIES J.J., 1976. The groundwater outcrop-erosion model; evolution of the stream network in the Netherlands. J. Hydrol. 29: 43-50.

De VRIES J.J., 1994. Dynamics of the interface between streams and groundwater systems in lowland areas, with references to stream net evolution. J. Hydrol. 155: 39-56.

Dietrich W.E. \& Dunne T., 1993. The channel head. In: K. Beven, M.J. Kirkby (eds.), Channel network hydrology. Wiley, Chichester: 175-219.

DunNE T., 1980. Formation and controls of channel networks. Prog. Phys. Geog. 4: 211-239.

GERLACH T., 1966. Współczesny rozwój stoków w dorzeczu górnego Grajcarka (Beskid Wysoki - Karpaty Zachodnie) (Present-day slopes evolution in the upper Grajcarek catchment (High Beskid, Western Carpathians)). Pr. Geogr. IG PAN 52: 1-111.

Gomi T., SidLE R.C. \& Richardson J.S., 2002. Understanding processes and downstream linkages of headwater systems. BioScience 52(10): 905-916.

HACK J.T. \& Goodlet J.C., 1960. Geomorphology and forest ecology of a mountain region in the Central Appalachians. Washington (DC). U.S. Geol. Surv. Prof. Pap. 347: $1-66$.

Higgins C.G., 1982. Drainage systems developed by sapping on Earth and Mars. Geology 10: 147-152.

Higgins C.G. \& Coates D.R. (eds.), 1990. Groundwater geomorphology: The role of subsurface water in Earth-surface processes and landforms. Geol. Soc. Am. Spec. Pap. 252: 1-265.

Higgins C.G., 1984. Piping and sapping: Development of landforms by groundwater outflow. In: R.G. LaFleur (ed.), Groundwater as a geomorphic agent. Allen\&Unwin, Boston: $18-58$

Howard A.D. \& McLANE C.F., 1988. Erosion of cohesionless sediment by groundwater seepage. Water Resour. Res. 24: 1659-1674.

KostrZEWSKi A. \& ZwOLIŃSKI Z., 1992. Udział denudacji chemicznej i mechanicznej we współczesnym systemie geo- 
morficznym górnej Parsęty (Pomorze Zachodnie) (The contribution of chemical and mechanical denudation to the contemporary geomorphic system of the upper Parsęta river). Pr. Geogr. IGPZ PAN 155: 11-45.

KostrzeWski A., Zwoliński Z., ANDrZejewski L., Florek W., Mazurek M., Niewiarowski W., Podgórski Z., Rachlewicz G., Smolska E., Stach A., Szmańda J. \& SzPikowski J., 2008. Współczesny morfosystem strefy młodoglacjalnej (Present-day morphosystem of young glacial zone). Landform Analysis 7: 7-11.

KRZEMIŃSKI T., 1989. Powiązanie form dolinnych środkowej Polski z obiegiem wody w małych zlewniach (The relationships of Central Polish valley forms to water cycle in small drainage basins). Acta Geographica Lodziensia 59: 95-119.

LAFLEUR R.G. (ed.), 1984. Groundwater as a geomorphic agent. Allen\&Unwin, Boston.

LAWLER D.M., 1993. Needle ice processes and sediment mobilization on river banks: the River Ilston, West Glamorgan, UK. J. Hydrol. 150: 81-114.

LobKovsky A.E., Smith B.E., Kudrolli A., Mohrig D.C. \& RothMAN D.H., 2007. Erosive dynamics of channels incised by subsurface water flow. J. Geophys. Res. 112, F03S12.

MAKSYMiUK Z. \& MoniewsKi S., 2000. Hydrologiczna i krajobrazowa rola źródeł małej zlewni w zachodniej części strefy krawędziowej Wzniesień Łódzkich (Hydrological and landscape role of the small drainage basin springs located in the western part of the Łódź Upland margin zone). Folia Geogr. Phys. 5: 67-81.

MAZUREK M., 2006. Morphometric differences in channel heads in a postglacial zone (Parsęta catchment, West Pomerania). Questiones Geographicae 25(A): 39-47.
MAZUReK M., 2010. Hydrogeomorfologia obszarów źródliskowych (dorzecze Parsęty, Polska NW) (Hydrogeomorphology of channel heads (the Parsęta drainage basin, NW Poland)). Seria Geografia 92: 1-308. Wyd. Naukowe UAM, Poznań.

MonIEWSKI P., 2004. Źródła okolic Łodzi (Springs near Łódź). Acta Geogr. Lodziensia 87: 1-140.

NASH D.J., 1996. Groundwater sapping and valley development in the Hackness Hills, North Yorkshire, England. Earth Surf. Processes Landf. 21: 781-795.

ONDA Y., 1994. Seepage erosion and its implication to the formation of amphitheatre valley heads: a case study at Obara, Japan. Earth Surf. Processes Landf. 19: 627-640.

Osadowski Z., Mazurek M. \& Dobrowolski R., 2009. Structure and development conditions of spring mires in the Parsęta basin (Western Pomerania). In: A. Łachacz (ed.), Wetlands - their functions and protection. Department of Land Reclamation and Environmental Management, University of Warmia and Mazury in Olsztyn: 107-124.

Sснumm S.A., Boyd K.F., Wolff C.G. \& Spitz W.J., 1995. A ground-water sapping landscape in the Florida Panhandle. Geomorphology 12: 281-297.

Schumm S.A. \& Phillips L., 1986. Composite channels of the Canterbury Plain, New Zealand: a Martian analog? Geology 14: 326-329.

TANAKA T., 1982. The role of subsurface water exfiltration in soil erosion processes. IAHS Publ. 137: 73-80.

UChupi E. \& Oldale R.N., 1994. Spring sapping origin of the enigmatic relict valleys of Cape Cod and Martha's Vineyard and Nantucket Islands, Massachusetts. Geomorphology 9: 83-95.

YOUNGER P.L., 2007. Groundwater in the environment. An introduction. Blackwell Publishing, Oxford. 